\title{
INFLUENCE OF DESTINATION IMAGE AND TRAVEL EXPERIENCE TOWARDS REVISIT INTENTION IN YOGYAKARTA AS TOURIST DESTINATION
}

\author{
Ghoitsa Rohmah Nurazizah ${ }^{(1)}$, Sri Marhanah ${ }^{(2)}$ \\ (1)(2) Program Studi Manajemen Resort dan Leisure, \\ Universitas Pendidikan Indonesia \\ srimarhanah@upi.edu,ghoitsa.rohmah@upi.edu
}

Submitted : 24 December 2019 Revised:1 March 2020

Accepted :27 March 2020

\begin{abstract}
ABSTRAK
Citra yang baik tentang destinasi wisata dapat menyebabkan wisatawan merespons secara positif dengan mengunjungi kembali niat dan juga menarik lebih banyak wisatawan potensial. Yogyakarta sebagai Provinsi Daerah Istimewa adalah tujuan wisata terbesar kedua setelah Bali di Indonesia. Peluncuran slogan "Jogja Istimewa" diharapkan dapat memberikan gambaran destinasi khusus dan pengalaman wisata yang menciptakan emosi positif bagi wisatawan sehingga mereka nantinya dapat mempengaruhi keputusan mereka untuk berkunjung lagi. Tujuan dari penelitian ini adalah untuk menganalisis pengaruh gambar tujuan dan pengalaman perjalanan pada niat untuk mengunjungi kembali Destinasi Wisata. Metode yang digunakan dalam penelitian ini adalah penelitian deskriptif dan verifikatif. Hasil penelitian menunjukkan gambar objektif (X1) dari niat perilaku secara langsung lebih besar daripada efek tidak langsung. Efek langsung dari gambar tujuan (X1) adalah 0,114, sedangkan efek tidak langsung adalah $-0,005$. Oleh karena itu, peran variabel intervening (kepuasan bepergian Y) tidak signifikan untuk memperkuat pengaruh citra tujuan pada niat perilaku. pengaruh pengalaman bepergian (X2) pada niat perilaku (Z) secara langsung lebih besar dari efek tidak langsung. Efek langsung dari pengalaman bepergian (X2) adalah 0,808, sedangkan efek tidak langsung adalah -0,022. Oleh karena itu, peran variabel intervening (kepuasan bepergian Y) tidak signifikan untuk memperkuat efek pengalaman bepergian pada niat perilaku.
\end{abstract}

Kata Kunci: Citra Destinasi, Niat Berkunjung Kembali, Pengalaman Perjalanan

\section{ABSTRACT}

A good image of the tourist destination can cause tourists to respond positively by revisit intention and also attracting more potential tourists. Yogyakarta as a Special Region Province is the second largest tourist destination after Bali in Indonesia. The launching of the slogan "Jogja Istimewa" is expected to provide an image of special destinations and tourist experiences that create positive emotions for tourists so that they can later influence their decision to visit again. The purpose of this study was to analyze the influence of destination images and travel experiences on the intention to revisit Tourism Destinations. The method used in this research was descriptive and verification research. The results showed the objective picture (X1) of the behavioral intention was directly greater than the indirect effect. 
Sri Marhanah and Ghoitsa Rohmah Nurazizah: Influence of Destination Image and

Travel Experience Towards Revisit Intention in Yogyakarta as Tourist Destination

The direct effect of the destination image (X1) is 0.114 , while the indirect effect is -0.005 . Therefore, the role of the intervening variable (satisfaction of traveling $Y$ ) is not significant to strengthen the influence of the goal image on behavioral intention. the effect of traveling experience $(\mathrm{X} 2)$ on behavioral intention $(\mathrm{Z})$ is directly greater than the indirect effect. The direct effect of the traveling experience $(X 2)$ is 0.808 , while the indirect effect is -0.022 . Therefore, the role of the intervening variable (satisfaction of traveling $Y$ ) is not significant to strengthen the effect of the traveling experience on behavioral intention.

\section{Keywords: Destination Image, Revisit Intention, Travel Experiences}

\section{INTRODUCTION}

Tourist destinations are very dependent on tourist loyalty to be able to survive and compete with other tourist destinations. Loyalty itself is a commitment to return or repurchase selected products or services in the future, related to interests and marketing efforts that have the potential to change (Hurriyati, 2005). Nowadays, more studies have tried to find reasons for tourists to visit again and are willing to recommend tourist destinations they have visited (Chen \& Tsai, 2007); (Chi \& Qu, 2008). Several factors have been identified, including destination image, high quality service or travel, and perceived value of travel satisfaction (Gallarza, Saura, \& Garc1'a). With the rapid development of tourism and increasingly fierce market competition, destination image has become a concern for academics and industry. This happens because the perception of the destination image is a factor that influences the success of tourism development, and is also a vital aspect in formulating a tourism destination marketing strategy (Chen \& Tsai, 2007). An attractive destination image perception will make tourists more satisfied and loyal (Chi \& Qu, 2008); (Mohan, 2010).

Yogyakarta Special Region Province is a destination for local and foreign tourists and the second largest tourist destination after Bali in Indonesia. Various tourist attractions are found in this province both natural, cultural, and special interests. When depicted from the type of attraction, Yogyakarta has a complete one. From the aspect of cultural and heritage tourism, Yogyakarta has a number of tourist attractions, including
Temple of Prambanan and Ratu Boko, Keraton Kasultanan Yogyakarta Hadiningrat, Kota Tua Kota Gedhe, Kings Mataram tomb, and traditional art which is still maintained and sustainable (Yogyakarta Tourism Government Office, 2018). The attraction which is supported by aspects of community life, still holds fast to the way of life of Javanese people. This strength is reflected in the activities of customs, language, social community, and art. Tourism for is already the main source of livelihood. The most unique thing from the overall development of the industry in, usually structural changes always start from the agricultural structure to manufacturing, then to the service sector. But what happened in Yogyakarta was a leap from agriculture to the service sector, as well as the fact that the service sector was a superior and dominant sector (Sulistya, 2016).

Campaign activity for the year of tourist visits continues to be driven by government policies that should target 480,000 for foreign tourists and 4.8 million domestic tourists (2018). Therefore it is important for tourist destinations to understand the different preferences and behaviors of various types of tourists who come. In view of this situation, the government launched a new slogan, "Special Jogja", as an effort to increase the enthusiasm of all tourism stakeholders to realize truly special tourism. The image of this privilege is expected to be reflected in its good governance, good management of the Tourism Attraction Management, and the quality of the tourism industry. 
Sri Marhanah and Ghoitsa Rohmah Nurazizah: Influence of Destination Image and

Travel Experience Towards Revisit Intention in Yogyakarta as Tourist Destination

However, it must be realized that tourism activities are not only limited to the publication of destination images. A good tourist destination is a destination that is able to provide tourist facilities that suit the needs of tourists. Therefore a tourist destination must be supported by the provision of facilities (transportation, accommodation); service (quality and quantity of human resources, professionalism, speed, accuracy, skills and friendliness); as well as tourist attractions that are prepared carefully and seriously. It aims to provide convenience and meet the needs of tourists during a visit. The facility itself is anything that is provided by the service provider to be used and enjoyed by the customer which aims to provide the maximum level of satisfaction (Kotler \& Keller, 2009). If tourism facilities can provide maximum satisfaction to tourists, then it becomes a good basis so that tourists are willing to visit again and are willing to tell positive things to others related to the destinations they have visited.

The preparation of these three aspects is an effort to provide and offer quality tourism products in accordance with the destination image that is intended to be formed, so as to increase the trust of tourists in the destinations visited. Tourists will actually choose tourist destinations that can cause positive emotions and eliminate negative emotions when they buy travel products. A good image of a tourist destination can cause tourists to respond positively by visiting again and also attracting more potential tourists to participate in the visit (Chen \& Tsai, 2007).

Several studies have shown that destination image is an important aspect that influences tourist satisfaction. Therefore it is important for stakeholders managing Yogyakarta tourist destinations to formulate the right strategy in improving the destination image. The majority of studies on destination image to date have focused on destinations for a vacation, which is very different from Yogyakarta is the main attraction that is owned by the life and culture of the people combined with the attraction of nature tourism. Therefore, it is important to determine the influence of destination image and travel experience on tourist revisit intention in Yogyakarta. The interest of revisiting in this study is called revisit intention which is defined as the possibility of tourists to repeat activities or re-visit a destination (Lin, 2012). costumer experience is an internal and subjective response from consumers who need contact with the company, both direct and indirect contact. Direct contact generally occurs during purchases, usage and services, and is usually initiated by tourists (Rageh, Melewar, \& Woodside, 2013).

On the contrary, indirect contact most involves unplanned meetings with representatives of a company's products, services or brands and accepts forms of word-of-mouth recommendations or criticisms, advertisements, news reports and reviews. According to the above definition, in the context of traveling, it can be interpreted that travel experience is an experience that is obtained by tourists both directly and indirectly regarding the service process, management, facilities, and how a consumer interacts with the manager and with other tourists. This, in return will shape the cognitive, emotional, and behavioral responses of tourists, will also leave experiences in the memories of tourists.

\section{LITERATURE REVIEW}

Based on the background that has been described, the statements and phenomena above, the purpose of this study is to 1) Identify the destination image in Yogyakarta Tourism Destinations, 2) Identify the description of the satisfaction of the experience of traveling in Yogyakarta Tourism Destinations, 3) Identify the picture of revisit intention in the Destinations Yogyakarta Tourism, and 4) Analyzing the influence of destination image and traveling experiences on revisit intention in Yogyakarta Tourism Destinations. 
Sri Marhanah and Ghoitsa Rohmah Nurazizah: Influence of Destination Image and

Travel Experience Towards Revisit Intention in Yogyakarta as Tourist Destination

Relationship between Destination Image, Travel Experience Satisfaction, and Returning Wishes

When an individual sees the image of a destination as positive, it is very likely that his satisfaction with the destination will be high (Castro, Amario, \& Ruiz, 2007); (Chen $\&$ Tsai, 2007). Castro et al. (Castro, Amario, \& Ruiz, 2007) further found that destination image played an important role in assessing satisfaction and return visits.

From what has been discussed it is hoped that it can be proven 1-3 hypotheses in research in Yogyakarta Tourism Destinations:

Hypothesis 1. Travelers with a more positive assessment of the destination image will have a higher level of satisfaction), Hypothesis 2. A better destination image influences the prospective behavior of tourists more positively, and Hypothesis 3. A higher level of overall satisfaction with traveling compared to straight with prospective travelers more positive behavior.

\section{Customer Experience}

There are eight dimensions of customer experience (Rageh, Melewar, \& Woodside, 2013) however the authors only examined six dimensions related to the object of research. The six dimensions are:

1. Comfort. Qualitative studies indicate that the decision of consumers in determining the destination for travel is closely related to the desire to get relaxation.

2. Educational. Educational experience or "learning while playing" is a mixture of exploration, exploration, mental stimulation and enthusiasm.

3. Hedonic. The hedonic dimension symbolizes enthusiasm, pleasure, and easy to remember.

4. Novelty. The need for new things leads to the desire to go from a recognized place to an unfamiliar place, or to search for new experiences, sensations and adventures, and the study identifies four dimensions of the Novelty paradigm namely change from routine, thrill, boredom alleviation, and surprise.
5. Safety. In the tourism literature, there is agreement that there is a relationship between crime and tourism, and in fact the crime rate is higher in tourist areas.

6. Beauty. Beauty is "an aspect of the idealization of experience in which an object, sound and concept is believed to possess the qualities of formal perfection".

\section{Revisit Intention}

Revisit intention is the possibility of tourists to repeat activities or re-visit a destination. There are four impacts that can cause the intention to visit again, namely:

1. Travel Motivation. Investigate the impact of various motivational factors on tourist attitudes during a visit to a destination and in the intention of visiting again

2. Past Experience. To examine the effect of past tourism experiences on tourists when visiting a destination and in the intention of revisiting.

3. Perceived Contstrait. To investigate the influence or perceived constraints on the intention of tourists to visit again.

4. Attitude. To measure the extent to which tourist attitudes in mediating the impact of certain factors on the intention to visit again. Dimensions used in this study: a. Intention To Recommend (Desire to recommend to others) and $b$. Intention To Revisit (Desire to visit again).

\section{MATERIAL AND METHOD}

Based on the variables studied, the research method uses descriptive and verification research methods. To achieve the goals we set in examining the proposed hypothesis, a questionnaire was developed to collect data on respondents' perceptions regarding destination image, travel experience, satisfaction, behavioral intentions, and sociodemographic information. To produce a complete list of items to measure destination image in Yogyakarta, we apply an analysis through structured interviews with question items that refer to the indicators specified in similar studies (Liu, Li, \& Kim, 2015). $424 / 5000$ 
Sri Marhanah and Ghoitsa Rohmah Nurazizah: Influence of Destination Image and

Travel Experience Towards Revisit Intention in Yogyakarta as Tourist Destination

Respondents were then asked to indicate their level of agreement with statements about each of the 13 destination image items with a 5-point Likert type scale, from "strongly disagree $(=1)$ " to "Strongly agree $(=5)$ ". For indicators of satisfaction and behavior

prospectively, we adopted a direct measurement scale where respondents were asked to rate their overall satisfaction with three items (Chen \& Tsai, 2007), namely the intention to return, the intention to recommend to friends and relatives, as well as the intention to tell positive things about the destination to others ( $\mathrm{Liu}, \mathrm{Li}, \& \mathrm{Kim}$, 2015). The sources of measurement items for construction are summarized in Table 1.

Table 1. Operationalization of Variables Variables

Destination

Image (Liu, Li, Indicators

\& Kim, 2015)

\begin{tabular}{|c|c|c|}
\hline & $\begin{array}{l}\text { c. } \\
\text { d. } \\
\text { e. } \\
\text { f. } \\
\text { g. } \\
\text { h. } \\
\text { i. } \\
\text { j. } \\
\text { k. } \\
\text { 1. } \\
\text { m. } \\
\text { n. }\end{array}$ & $\begin{array}{l}\text { Interesting local food } \\
\text { and drinks } \\
\text { Diversity of cultural } \\
\text { appeal } \\
\text { A suitable place to } \\
\text { hold an event } \\
\text { Convenient mode of } \\
\text { transportation } \\
\text { Availability of TIC } \\
\text { Quality TIC } \\
\text { Easy access to } \\
\text { attractions } \\
\text { A comfortable } \\
\text { atmosphere for } \\
\text { traveling } \\
\text { Beautiful and } \\
\text { protected } \\
\text { environment from } \\
\text { pollution } \\
\text { Exotic tourist } \\
\text { destinations } \\
\text { Diversity of shopping } \\
\text { products } \\
\text { Lively nightlife }\end{array}$ \\
\hline $\begin{array}{l}\text { Traveling } \\
\text { Satisfaction (Liu, } \\
\mathrm{Li}, \quad \& \quad \mathrm{Kim}, \\
2015)\end{array}$ & $\begin{array}{l}\text { a. } \\
\text { b. }\end{array}$ & $\begin{array}{l}\text { I really enjoyed this } \\
\text { traveling trip } \\
\text { My choice to visit } \\
\text { Yogyakarta is very } \\
\text { appropriate } \\
\text { The travel experience } \\
\text { that I got while in } \\
\text { Yogyakarta was as I } \\
\text { expected }\end{array}$ \\
\hline
\end{tabular}

\begin{tabular}{|c|c|}
\hline Variables & Indicators \\
\hline $\begin{array}{l}\text { Revisit Intention } \\
\text { (Liu, Li, \& Kim, } \\
2015 \text { ) }\end{array}$ & $\begin{array}{l}\text { a. I plan to visit } \\
\text { Yogyakarta again in } \\
\text { the future } \\
\text { b. I will recommend } \\
\text { Yogyakarta to friends } \\
\text { and relatives } \\
\text { c. I will say something } \\
\text { positive about } \\
\text { Yogyakarta to others }\end{array}$ \\
\hline $\begin{array}{l}\text { Tourist } \\
\text { Experiece } \\
\text { (Yuniawati \& } \\
\text { Finardi, 2016) }\end{array}$ & $\begin{array}{ll}\text { a. } & \text { (comfort) } \\
\text { b. } & \text { (education) } \\
\text { c. } & \text { (hedonic) } \\
\text { d. } & \text { (novelty) } \\
\text { e. } & \text { (beauty) } \\
\text { f. } & \text { (safety) }\end{array}$ \\
\hline
\end{tabular}

Sources: processed by researchers

Through this research it is hoped that it can explore and verify how the level of satisfaction and revisit intention of tourists is influenced by the image perceived by them using the structural equation model (SEM). The series of data analysis starts from the stages of testing the validity and reliability. How to tell about how well the instrument was developed with the concept of certain steps aimed at measuring certain variables (Sekaran \& Bougie, 2016). From this study what will be tested is the validity of the destination image instrument as variable X1 and travel satisfaction as variable $\mathrm{X} 2$ and revisit intention as variable $\mathrm{Y}$.

While reliability is a way of testing about how consistent the concept of the measuring instrument (Sekaran \& Bougie, 2016). The formula used to measure reliability in this study uses the Cronbach Alpha test because the alternative answers to the research instruments are more than two. The reliability calculation of the questions is done with the help of the SPSS Statistics 20 program for windows.

Second, that is the verification of data analysis using MSI (Method of Successive Interval) and multiple linear regression analysis. The scale used in this study is the ordinal scale, which is a rating scale that shows a sequence of preferences or judgments. The ordinal scale needs to be transformed into an interval scale using the MSI method with the following steps: 
Sri Marhanah and Ghoitsa Rohmah Nurazizah: Influence of Destination Image and

Travel Experience Towards Revisit Intention in Yogyakarta as Tourist Destination

Calculate the frequency (f) for each answer choice based on the results of the respondent's answer to each question.

1. Based on the frequency obtained for each question, proportional calculation ( $p$ ) of each answer choice is done by dividing the frequency by the number of respondents.

2. Based on the proposition, the cumulative proportion calculation is then performed for each answer choice

3. Determine the value of the $\mathrm{Z}$ limit (normal table) for each question and each answer choice

4. Determine the average interval value for each answer choice.

\section{Data Collection}

This study targets tourists who have traveled to Yogyakarta with an age limit of 17 years or more. For the sample of respondents, this research applies the intercept method field. The data points are at 10 tourist attractions located in Yogyakarta tourist destinations, train stations, and around hotels and tourist gathering centers in Malioboro. In this study, sampling is done by quota sampling technique by spreading random sampling. The number of respondents obtained was 391 respondents.

\section{RESULT AND DISCUSSION \\ Destination Image Factor Analysis in Yogyakarta Tourism Destinations}

There are 14 destination image factors analyzed, namely 1) diversity of events and festivals, 2) interesting culture, 3) typical local food and drinks, 4) diversity of attractions, 5) suitable places to hold events, 6) modes of transportation that are comfortable, 7) availability of TIC, 8) quality of TIC, 9) easy access to tourist attractions, 10) comfortable atmosphere for traveling, 11) beautiful and protected environment from pollution, 12) exotic tourist destinations, 13) diversity of products shopping, and 14) lively nightlife (Liu, Li, \& Kim, 2015).

Destination image factors that are considered dominant for respondents are obtained through factor analysis starting with the Kaiser-Mayer-Olkin Test (KMO) and
Bartlett Test. The KMO test results in this study indicate that the sample taken is sufficient with an adequacy value of 0.803 (greater than 0.5), while the Bartlett Test shows a significance level of 0.000 (less than 0.005) which means the data can be continued in the next analysis (Table 3 ) .

Table 3. KMO dan Bartlett test

\begin{tabular}{|c|c|c|}
\hline \multicolumn{2}{|c|}{$\begin{array}{c}\text { Kaiser-Mayer-Olkin Measure of } \\
\text { Sampling Adequacy }\end{array}$} & 0.803 \\
\hline Bartlett's & Approx Chi-Square & 1364.833 \\
\hline Test & $\mathrm{df}$ & 91 \\
\hline Sphericity & Sig. & 0.000 \\
\hline
\end{tabular}

The next stage is to look at the Anti-Image Matrix table, this is done to determine the appropriate variables to use in the subsequent analysis process. In the table there is the code 'a' which means the sign for MSA (Measure of Sampling Adequacy). Variables that are feasible to use in the subsequent analysis process are variables that have an MSA value $>0.5$.

The analysis then continues by looking at the adequacy of the extraction values for each variable. As explained earlier, variables with extraction values below 0.5 are considered not to meet the requirements for inclusion in further analysis. In our research, 4 (four) repetitions are needed until all extraction values in the communalities test meet the factor analysis requirements. At the end of the Fourth Round, there are 6 (six) variables of the 14 (fourteen) destination image factors that must be excluded from the analysis because they do not meet the extraction value (the value is below 0.5 ), namely the image as a venue (ID-5), convenience of transportation modes (ID-6), ease of accessibility (ID-9), comfort of DTW atmosphere (ID-10), beautiful and maintained environment (ID11), exotic tourist attractions (ID-12).

Table 4. Communalities Extraction Value of Destination Image Variables

\begin{tabular}{llllll}
\hline $\begin{array}{l}\text { Varia } \\
\text { bles }\end{array}$ & $\begin{array}{l}\text { Init } \\
\text { ial }\end{array}$ & $\begin{array}{l}\text { Extrac } \\
\text { tion 1 }\end{array}$ & $\begin{array}{l}\text { Extrac } \\
\text { tion 2 }\end{array}$ & $\begin{array}{l}\text { Extrac } \\
\text { tion 3 }\end{array}$ & $\begin{array}{l}\text { Extrac } \\
\text { tion 4 }\end{array}$ \\
\hline ID-1 & 1.0 & .503 & .543 & .529 & .525 \\
& 00 & & & & \\
ID-2 & 1.0 & .704 & .698 & .724 & .723 \\
& 00 & & & & \\
ID-3 & 1.0 & .540 & .531 & .532 & .542
\end{tabular}


Sri Marhanah and Ghoitsa Rohmah Nurazizah: Influence of Destination Image and

Travel Experience Towards Revisit Intention in Yogyakarta as Tourist Destination

\begin{tabular}{|c|c|c|c|c|c|}
\hline $\begin{array}{l}\text { Varia } \\
\text { bles }\end{array}$ & $\begin{array}{l}\text { Init } \\
\text { ial }\end{array}$ & $\begin{array}{l}\text { Extrac } \\
\text { tion 1 }\end{array}$ & $\begin{array}{l}\text { Extrac } \\
\text { tion } 2\end{array}$ & $\begin{array}{l}\text { Extrac } \\
\text { tion } 3\end{array}$ & $\begin{array}{l}\text { Extrac } \\
\text { tion } 4\end{array}$ \\
\hline ID-4 & $\begin{array}{l}00 \\
1.0 \\
00\end{array}$ & .571 & .570 & .564 & .566 \\
\hline ID-5 & $\begin{array}{l}1.0 \\
00\end{array}$ & .305 & $\begin{array}{l}\text { (exclud } \\
\text { ed) }\end{array}$ & $\begin{array}{l}\text { (exclud } \\
\text { ed) }\end{array}$ & $\begin{array}{l}\text { (exclud } \\
\text { ed) }\end{array}$ \\
\hline ID-6 & $\begin{array}{l}1.0 \\
00\end{array}$ & .439 & $\begin{array}{l}\text { (exclud } \\
\text { ed) }\end{array}$ & $\begin{array}{l}\text { (exclud } \\
\text { ed) }\end{array}$ & $\begin{array}{l}\text { (exclud } \\
\text { ed) }\end{array}$ \\
\hline ID-7 & $\begin{array}{l}1.0 \\
00\end{array}$ & .739 & .794 & .834 & .842 \\
\hline ID-8 & $\begin{array}{l}1.0 \\
00\end{array}$ & .762 & .776 & .824 & .836 \\
\hline ID-9 & $\begin{array}{l}1.0 \\
00\end{array}$ & .371 & $\begin{array}{l}\text { (exclud } \\
\text { ed) }\end{array}$ & $\begin{array}{l}\text { (exclud } \\
\text { ed) }\end{array}$ & $\begin{array}{l}\text { (exclud } \\
\text { ed) }\end{array}$ \\
\hline ID-10 & $\begin{array}{l}1.0 \\
00\end{array}$ & .428 & $\begin{array}{l}\text { (exclud } \\
\text { ed) }\end{array}$ & $\begin{array}{l}\text { (exclud } \\
\text { ed) }\end{array}$ & $\begin{array}{l}\text { (exclud } \\
\text { ed) }\end{array}$ \\
\hline ID-11 & $\begin{array}{l}1.0 \\
00\end{array}$ & .725 & .277 & $\begin{array}{l}\text { (exclud } \\
\text { ed) }\end{array}$ & $\begin{array}{l}\text { (exclud } \\
\text { ed) }\end{array}$ \\
\hline ID-12 & $\begin{array}{l}1.0 \\
00\end{array}$ & .506 & .500 & .426 & $\begin{array}{l}\text { (exclud } \\
\text { ed) }\end{array}$ \\
\hline ID-13 & $\begin{array}{l}1.0 \\
00\end{array}$ & .678 & .632 & .677 & .713 \\
\hline ID-14 & $\begin{array}{l}1.0 \\
00 \\
\end{array}$ & .720 & .572 & .645 & .705 \\
\hline
\end{tabular}

Extraction Method: Principal Component Analysis.

Explanation:

D-1 = Various Events and Festivals ID-8 = Quality TIC

ID-2 = Attractive Culture ID-9 = Easy Access

ID-3 = Local Cuisine ID-10 = Comfortable Atmosphere

ID-4 = Multiple Attractiveness ID-11 = Beautiful and Secure Environment

ID-5 = Appropriate for the event ID-12 = Exotic DTW ID-6 $=$ Convenient Mode of Transportation ID-13 = Variety of Shopping Products

ID-7 = Availability of TIC ID-14 = Lively Night Life

The eight destination images that are not eliminated, are then grouped into 3 new factors through the analysis of Eigenvalues values of more than 1 . Values of more than 1 indicate the effect of variables on the formation of characteristic matrix factors. From the value of variance, the three factors are formed which are grouped into 4 destination images in factor 1,2 images in factor 2, and 2 images in factor 3. The first destination image consists of interesting culture, diversity of attractions, diversity of events and festivals, and the uniqueness culinary. This factor is then named the Attraction Factor Diversity. Then, the second factor consists of the Tourist Information
Center availability factor and the quality of the Tourist Information Center, which is named the Tourist Information Access Factor. Furthermore, the third factor consists of a diversity of products for shopping and lively nightlife, which is named the Tourism Support Activity Factor. From the analysis of factors that have been carried out, it can be concluded that the image of the Yogyakarta destination is very strongly valued as a destination with a diversity of tourist attractions, easy access to tourist information and adequate tourist support activities.

Analysis of Travel Experience Satisfaction in Yogyakarta Tourism Destinations. The experience of traveling was assessed from several indicators that were adapted (Yuniawati \& Finardi, 2016) namely perceptions related to the experience of traveling in the aspects of comfort, education, pleasure/ hedonic, experience of new things (novelty), security (safety), and also beauty. Using SPSS, the following are the results of the statistical descriptive analysis (Table 7).

Table 7. Description of Travel Experience Statistics

\begin{tabular}{|c|c|c|c|c|c|c|}
\hline $\begin{array}{l}\text { Trav } \\
\text { el } \\
\text { exper } \\
\text { ience }\end{array}$ & $\begin{array}{l}\text { Mini } \\
\text { mum }\end{array}$ & $\begin{array}{l}\text { Maxi } \\
\text { mum }\end{array}$ & $\begin{array}{l}\text { M } \\
\text { ea } \\
\text { n }\end{array}$ & $\begin{array}{l}\text { Interp } \\
\text { retasi } \\
\text { Mean }\end{array}$ & $\begin{array}{l}\text { Std. } \\
\text { Devi } \\
\text { ation }\end{array}$ & $\begin{array}{l}\text { Vari } \\
\text { ance }\end{array}$ \\
\hline $\begin{array}{l}\text { Comf } \\
\text { ort }\end{array}$ & 1.00 & 5.21 & $\begin{array}{l}3.4 \\
2\end{array}$ & $\begin{array}{l}\text { Hesita } \\
\text { nt }\end{array}$ & $\begin{array}{l}0.77 \\
674\end{array}$ & $\begin{array}{l}0.60 \\
3\end{array}$ \\
\hline $\begin{array}{l}\text { Educ } \\
\text { ation }\end{array}$ & 1.00 & 4.74 & $\begin{array}{l}3.5 \\
9\end{array}$ & Agree & $\begin{array}{l}0.73 \\
471\end{array}$ & $\begin{array}{l}0.54 \\
0\end{array}$ \\
\hline $\begin{array}{l}\text { Hedo } \\
\text { nic }\end{array}$ & 1.00 & 4.60 & $\begin{array}{l}3.7 \\
4\end{array}$ & Agree & $\begin{array}{l}0.69 \\
358\end{array}$ & $\begin{array}{l}0.48 \\
1\end{array}$ \\
\hline $\begin{array}{l}\text { Novel } \\
\text { ty }\end{array}$ & 1.00 & 4.71 & $\begin{array}{l}3.6 \\
1\end{array}$ & Agree & $\begin{array}{l}0.80 \\
084\end{array}$ & $\begin{array}{l}0.64 \\
1\end{array}$ \\
\hline Safet & 1.61 & 5.53 & $\begin{array}{l}4.0 \\
9\end{array}$ & Agree & $\begin{array}{l}0.72 \\
344\end{array}$ & 0.52 \\
\hline $\begin{array}{l}\text { Beaut } \\
y\end{array}$ & 1.00 & 5.01 & $\begin{array}{l}4.0 \\
9\end{array}$ & Agree & $\begin{array}{l}0.86 \\
336\end{array}$ & $\begin{array}{l}0.74 \\
5\end{array}$ \\
\hline
\end{tabular}

$\mathrm{N}=391$ Respondents

Table 8. Rotation of matrix components

\begin{tabular}{lccc}
\hline \multirow{2}{*}{ Destination Image } & \multicolumn{3}{c}{ Component } \\
\cline { 2 - 4 } & $\mathbf{1}$ & $\mathbf{2}$ & $\mathbf{3}$ \\
\hline Unique Cultural ID & .849 & .026 & .047 \\
\hline $\begin{array}{l}\text { ID-Variety of } \\
\text { Attraction }\end{array}$ & .714 & .105 & .214 \\
\hline Attractive ID-Festival & .678 & .252 & -.039 \\
\hline Culinary ID & .655 & .111 & .317 \\
\hline
\end{tabular}


Sri Marhanah and Ghoitsa Rohmah Nurazizah: Influence of Destination Image and

Travel Experience Towards Revisit Intention in Yogyakarta as Tourist Destination

\begin{tabular}{|c|c|c|c|}
\hline \multirow{2}{*}{ Destination Image } & \multicolumn{3}{|c|}{ Component } \\
\hline & 1 & 2 & 3 \\
\hline ID-Qty TIC & .160 & .902 & .053 \\
\hline ID-Qlty TIC & .142 & .900 & .082 \\
\hline ID-Night Life & .060 & .002 & .837 \\
\hline Shopping ID & .216 & .124 & .807 \\
\hline \multicolumn{4}{|c|}{$\begin{array}{c}\text { Extraction Method: Principal Component Analysis. } \\
\text { Rotation Method: Varimax with Kaiser } \\
\text { Normalization. }\end{array}$} \\
\hline
\end{tabular}

From the variance values, the three factors formed can be grouped into 4 destination images on factor 1, 2 images on factor 2, and 2 images on factor 3 . The first destination image consists of attractive culture, diversity of attractions, diversity of events and festivals, and culinary specialties. This factor is then named the Attraction Factor Diversity. Then, the second factor consists of the Tourist Information Center availability factor and the quality of the Tourist Information Center, which is named the Tourist Information Access Factor. Furthermore, the third factor consists of a diversity of products for shopping and lively nightlife, which is named the Tourism Support Activity Factor.

With the average value of each indicator, the respondents agreed that traveling in Yogyakarta provided experience in the aspects of education, hedonism, novelty, safety, and beauty. On the other hand, respondents were hesitant about evaluating the comfort aspects gained during a tour in Yogyakarta.

In the aspect of education, respondents can provide their level of agreement on the realm of traveling in Yogyakarta to provide experience of quality activities and can explore deeper aspects of culture and history. Likewise in the hedonic aspect, respondents agreed that the experience of traveling while in Yogyakarta gave a feeling of having fun, made them more excited, and gave a high memory value (Rageh, Melewar, \& Woodside, 2013).

This is due to the fact that the hedonic dimension is symbolized by enthusiasm, pleasure, and easy to remember. Furthermore, with the novelty aspect, respondents agree that traveling in Yogyakarta gives them new experiences and can try new things. This is closely related to novelty, namely the need to go to a strange place, look for experiences, sensations, and new adventures (Rageh, Melewar, \& Woodside, 2013). Furthermore, in the aspect of safety and beauty, respondents agreed to feel safe and easy access, carry out safe activities, and avoid threats from the surrounding environment, also on the other hand they could immediately enjoy the beauty of the environment and the beauty of the natural surroundings. However, respondents were hesitant about finding comfort during a tour related to the use of facilities, both tourism facilities and infrastructure.

\section{Path Analysis Using Multiple Regression 1. Path coefficient test Model Regression 1}

Based on the test results of the coefficient of determination in Table 8 can be seen that the value of $\mathrm{R}$ (correlation) of 0.629 which means there is a strong relationship (correlation) between travel satisfaction (Y), $\mathrm{X} 1$ (destination image), and X2 (traveling experience) because the value of $\mathrm{R}$ is more greater than 0.5 .

Table 8. Model Summary (1)

\begin{tabular}{|c|c|c|c|c|}
\hline $\begin{array}{l}\text { Mo- } \\
\text { del }\end{array}$ & $\mathbf{R}$ & $\begin{array}{l}\text { R } \\
\text { Square }\end{array}$ & $\begin{array}{l}\text { Adjuste } \\
\text { d } \quad \text { R } \\
\text { Square }\end{array}$ & $\begin{array}{lr}\text { Std. } & \text { Error } \\
\text { of } & \text { the } \\
\text { Estimate }\end{array}$ \\
\hline 1 & .629 & .396 & .393 & .59905 \\
\hline & $\begin{array}{l}\text { Pred } \\
\text { Expe } \\
{[X 1]}\end{array}$ & $\begin{array}{l}\text { ctors: } \\
\text { cience }\end{array}$ & $\begin{array}{l}\text { (Constant } \\
2 \text { ], Image }\end{array}$ & $\begin{array}{l}\text { Travel } \\
\text { Destination }\end{array}$ \\
\hline b. & $\begin{array}{l}\text { Depe } \\
\text { Satis }\end{array}$ & ndent & Variable: & Tourist \\
\hline
\end{tabular}

The coefficient of determination (R Square) of 0.396 , if entered into the formula of the coefficient of determination will produce: $\mathrm{BC}=R 2 \times 100 \%=(0.396) \times 100 \%=39.6 \%$ Based on these calculations the coefficient of determination is $39.6 \%$. This shows that the test results of the coefficient of determination $\mathrm{X} 1$ (destination image) and X2 (traveling experience) contributed $39.6 \%$ to travel satisfaction (Y) in Yogyakarta destinations, 
Sri Marhanah and Ghoitsa Rohmah Nurazizah: Influence of Destination Image and

Travel Experience Towards Revisit Intention in Yogyakarta as Tourist Destination

the rest $(60.4 \%)$ is influenced by other variables not used in this study.

Table 9. Test F (1)

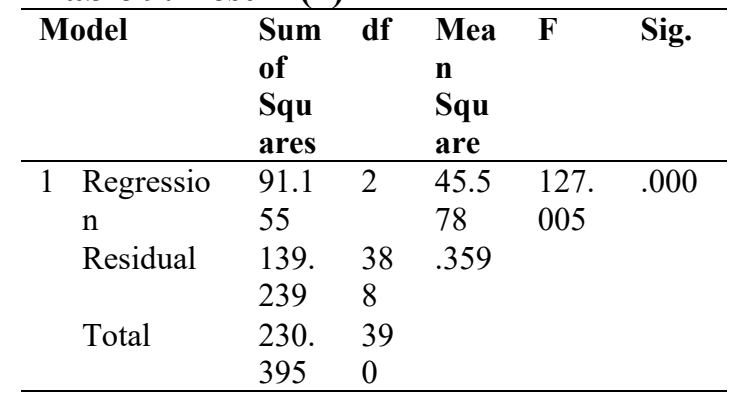

a. Dependent Variable: Tourist Satisfaction [Y]

b. Predictors: (Constant), Travel Experience [X2], Image Destination [X1]

Based on the results of the $\mathrm{F}$ test in Table 9 can be explained by using a significance level of 0.05 obtained Fcount of 127.005 thus Fcount $>$ Ftable with a significance level obtained $0.000<0.05$ so that simultaneously, the destination image and travel experience affect the satisfaction traveled in Yogyakarta destinations.

Table 10. T Test (1)

\begin{tabular}{|c|c|c|c|c|c|c|}
\hline \multirow{2}{*}{\multicolumn{2}{|c|}{ Model }} & \multicolumn{2}{|c|}{$\begin{array}{l}\text { Unstandardi } \\
\text { zed } \\
\text { Coefficients }\end{array}$} & $\begin{array}{l}\text { Stand } \\
\text { ardize } \\
\text { d } \\
\text { Coeffi } \\
\text { cients }\end{array}$ & \multirow[t]{2}{*}{$\mathbf{t}$} & \multirow[t]{2}{*}{ Sig } \\
\hline & & B & $\begin{array}{l}\text { Std. } \\
\text { Error }\end{array}$ & Beta & & \\
\hline \multirow[t]{6}{*}{1} & (Cons & - & .248 & & 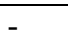 & .75 \\
\hline & $\operatorname{tant})$ & .078 & & & .315 & 3 \\
\hline & Image & .193 & .070 & .136 & 2.75 & .00 \\
\hline & $\begin{array}{l}\text { Desti } \\
\text { nation } \\
{[\mathrm{X} 1]}\end{array}$ & & & & 1 & 6 \\
\hline & Trave & .808 & .074 & .538 & 10.8 & .00 \\
\hline & $\begin{array}{l}1 \\
\text { Exper } \\
\text { ience } \\
{[\mathrm{X} 2]}\end{array}$ & & & & 88 & 0 \\
\hline
\end{tabular}

a. Dependent Variable: Tourist Satisfaction [Y]

Based on the $\mathrm{T}$ test results in Table 10 can be explained as follows:

1. Destination image variable (X1) has a $t$ count of 2.751 and a significance value of 0.006. So it can be said that the destination image has a significant effect on the satisfaction of traveling in Yogyakarta destinations because $t$ arithmetic $>\mathrm{T}$ table is 2.751 and sig $<0.05$ is $0.006<0.05$.

2. The travel experience variable (X2) has a $\mathrm{t}$ count of 10.888 and a significance value of 0.000 . So that it can be said that the experience of traveling also has a significant influence on the satisfaction of traveling visitors because $\mathrm{t}$ count $>\mathrm{t}$ table is $10.999>$ and $\operatorname{sig}<0.05$ ie 0.000 $<0.05$.

To find out how the simultaneous influence of the two $\mathrm{X}$ variables on $\mathrm{Y}$, the authors use multiple linear regression analysis techniques with the equation model obtained as follows: $\mathrm{Y}=-0,078+0,193 . \mathrm{X} 1+0,808 \mathrm{X} 2$

Based on the equation formula model, it can be explained as follows:

1. From the linear regression equation, it can be seen that constant a has a value of $-0,078$, it shows that if the destination image (X1) and travel experience (X2) have a value of 0 , then travel satisfaction (Y) has a value of -0.078 .

2. In the destination image (X1) obtained a regression coefficient of 0.193 which means that if the destination image variable increases by one unit, the satisfaction of the tour will increase by 0.193 . The regression coefficient value obtained is positive which means that the higher the level of destination imagery in Yogyakarta, the higher the satisfaction of traveling in Yogyakarta.

3. In the traveling experience (X2) obtained a regression coefficient of 0.808 which means that if the experience of traveling experience increases by one unit, the satisfaction of the trip will increase by 0.808 . The regression coefficient value obtained is positive which means that the higher the level of travel experience, the higher the satisfaction of traveling in Yogyakarta.

Model Regression 2

Based on the test results of the coefficient of determination in table 11 can be seen that the value of $\mathrm{R}$ (correlation) of 0.805 which 
Sri Marhanah and Ghoitsa Rohmah Nurazizah: Influence of Destination Image and

Travel Experience Towards Revisit Intention in Yogyakarta as Tourist Destination

means there is a strong relationship (correlation) between behavioral intention (Z), X1 (destination image), X2 (travel experience), and travel satisfaction (travel) $\mathrm{Y}$ ) because the value of $\mathrm{R}$ is greater than 0.5 .

Table 11 Model Summary (2)

\begin{tabular}{lllll}
\hline Model & $\mathrm{R}$ & $\begin{array}{l}\mathrm{R} \\
\text { Square }\end{array}$ & $\begin{array}{l}\text { Adjusted } \\
\text { R Square }\end{array}$ & $\begin{array}{l}\text { Std. Error of } \\
\text { the Estimate }\end{array}$ \\
\hline 2 & .805 & .647 & .644 & .38608 \\
\hline
\end{tabular}

a. Predictors: (Constant), Tourist Satisfaction [Y], Image Destination [X1], Travel Experience [X2]

b. Dependent Variable: Behavioral Intention [Z]

The coefficient of determination ( $\mathrm{R}$ Square) of 0.647 , if entered into the formula of the coefficient of determination will get a coefficient of determination of $64.7 \%$. This shows that the test results of the coefficient of determination X1 (destination image), X2 (traveling experience), and $\mathrm{Y}$ (travel satisfaction) contributed $64.7 \%$ to behavioral intention $(Z)$ in Yogyakarta destinations, the rest $(35.3 \%)$ is influenced by other variables which was not used in this study.

Table 12. Test F (2)

\begin{tabular}{|c|c|c|c|c|c|c|}
\hline \multicolumn{2}{|c|}{ Model } & $\begin{array}{l}\text { Sum } \\
\text { of } \\
\text { Squa } \\
\text { res }\end{array}$ & $\mathrm{df}$ & $\begin{array}{l}\text { Mea } \\
\mathrm{n} \\
\text { Squa } \\
\text { re }\end{array}$ & $\mathrm{F}$ & Sig. \\
\hline \multirow[t]{6}{*}{2} & Regressio & 105. & 3 & 35.2 & \multirow{4}{*}{$\begin{array}{l}236.6 \\
82\end{array}$} & \multirow[t]{6}{*}{.000} \\
\hline & $\mathrm{n}$ & 836 & & 79 & & \\
\hline & \multirow[t]{2}{*}{ Residual } & 57.6 & 38 & \multirow[t]{2}{*}{.149} & & \\
\hline & & 84 & 7 & & & \\
\hline & \multirow[t]{2}{*}{ Total } & 163. & 39 & & & \\
\hline & & 520 & 0 & & & \\
\hline
\end{tabular}

a. Dependent Variable: Behavioral Intention [Z]

b. Predictors: (Constant), Tourist Satisfaction [Y], Image Destination [X1], Travel Experience [X2]

Based on the results of the F test in Table 12 can be explained by using a significance level of 0.05 obtained an F count of 236,682 with an $F$ table of 236 so $F$ count $>F$ table with a significance level obtained 0,000 $<0.05$ so that simultaneously, destination image, travel experience, and travel satisfaction affect behavioral intention in Yogyakarta destinations.
Table 13. T Test (2)

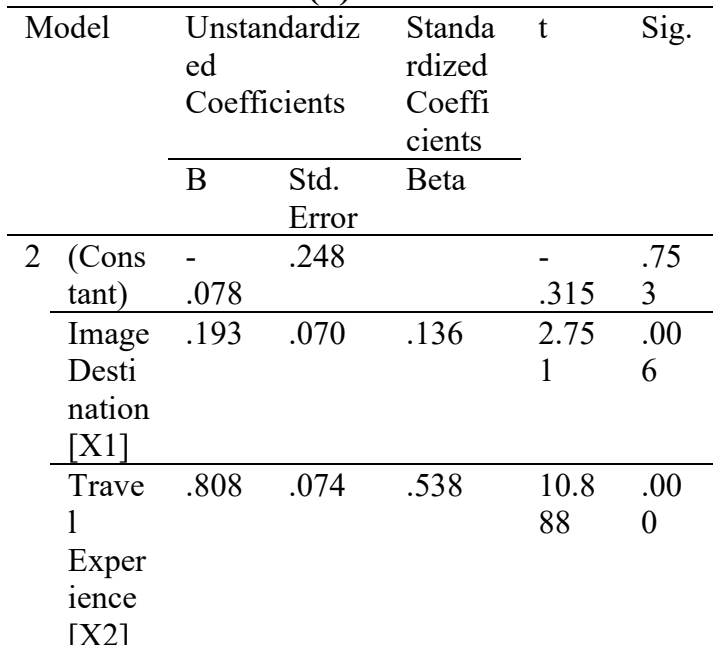

a. Dependent Variable: Tourist Satisfaction [Y] Based on the $\mathrm{T}$ test results in Table 13 can be explained as follows:

1. Destination image variable (X1) has a $t$ count of 2.486 and a significance value of 0.013 . So it can be said that the destination image has a significant influence on behavioral intention in Yogyakarta destinations because $t$ arithmetic $>\mathrm{t}$ table is $2.751>$ and sig $<0.05$ ie $0.013<0.05$.

2. The travel experience variable (X2) has a $t$ count of 17,698 and a significance value of 0,000 . So it can be said that the experience of traveling also has a significant effect on behavioral intention because $t$ arithmetic $>\mathrm{t}$ table is $17,698>$ and sig $<0.05$ ie $0,000<0.05$.

3. Meanwhile, the travel satisfaction variable (Y) as an intervening variable has a t-count of $-0,846$ and a significance value of 0.398 . So it can be said that the traveling canal does not have a significant effect on behavioral intention, because $t$ count $<\mathrm{t}$ table is $-0.846<1.990$ and sig $>$ 0.05 which is $0.398>0.05$.

Based on the results of these interpretations it can be said that the role of the $\mathrm{Y}$ variable as an intervening variable does not function because the significance value is more than 0.05 . Then in the second regression model, the 
Sri Marhanah and Ghoitsa Rohmah Nurazizah: Influence of Destination Image and

Travel Experience Towards Revisit Intention in Yogyakarta as Tourist Destination

equation model obtained as follows:

$$
\mathrm{Z}=-0,285+0,114 . \mathrm{X} 1+0,967 \mathrm{X} 2
$$

Based on the equation formula model, it can be explained as follows:Dari persamaan regresi linear kedua tersebut dapat dilihat bahwa konstanta a memiliki nilai sebesar 0,285 , hal tersebut menunjukan jika citra destinasi (X1) dan pengalaman berwisata (X2) bernilai 0 , maka behavioral intention (Z) memiliki nilai sebesar -0,285.

4. In the destination image (X1) obtained a regression coefficient of 0.114 which means that if the destination image variable increases by one unit, then behavioral intention will increase by 0.114 . The regression coefficient value obtained is positive which means that the higher the level of destination image in Yogyakarta, the higher the behavioral intention to Yogyakarta.

5. In the traveling experience (X2) obtained a regression coefficient of 0.967 which means that if the experience of traveling variable increases by one unit, then behavioral intention will increase by 0.967 . The regression coefficient value obtained is positive which means the higher the level of traveling experience, the higher the behavioral intention to Yogyakarta.

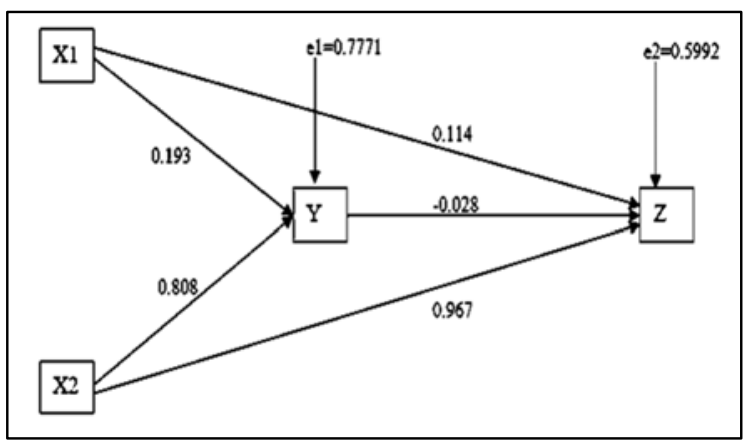

Figure1. Regression Model of two hypothesis

Following are two regression models that have been carried out, the path analysis model (footprint) is formed as in the chart above. However, because there is no significant influence value of the $\mathrm{Y}$ variable on the $\mathrm{Z}$ variable.

CONCLUSION
1. The influence of destination image (X1) through travel satisfaction $(\mathrm{Y})$ on behavioral intention $(\mathrm{Z})$

In theory (Liu, Li, \& Kim, 2015)), travel satisfaction $(\mathrm{Y})$ has an intervening role in strengthening the influence of destination image (X1) on behavioral intention (Z). But in our research, the effect of destination image (X1) on behavioral intention is directly greater than the indirect effect. The direct effect of the destination image (X1) is 0.114 , while the indirect effect is -0.005 . Therefore, the role of intervening variables (satisfaction of traveling Y) is not significant to strengthen the influence of destination images on behavioral intention.

2. Effect of traveling experience (X2) through traveling satisfaction (Y) on behavioral intention $(\mathrm{Z})$

In theory, (Liu, Li, \& Kim, 2015) travel satisfaction (Y) also has an intervening role in strengthening the effect of traveling experience (X2) on behavioral intention (Z). However, in our research, the influence of tourism (X2) on behavioral intention $(\mathrm{Z})$ is directly greater than the indirect effect. The direct influence of traveling experience (X2) is 0.808 , while indirectly is -0.022 . Therefore, the role of the intervening variable (satisfaction of traveling Y) is not significant to strengthen the effect of the experience of traveling on behavioral intention.

\section{ACKNOWLEDGEMENT}

The authors would like to give the highest gratitude to Resort and Leisure Management Program, Universitas Pendidikan Indonesia, for funding for this research.

\section{REFERENCES}

(2018). Retrieved from Yogyakarta Tourism Government Office: https://visitingjogja.com/

(2018). Retrieved from www.tribunjogja.com Castro, C., Amario, E., \& Ruiz, D. (2007). The Influence of Market Heterogenity on The Relationship Between a Destination's Image and Tourists 
Sri Marhanah and Ghoitsa Rohmah Nurazizah: Influence of Destination Image and

Travel Experience Towards Revisit Intention in Yogyakarta as Tourist Destination

Future Behavior. Tourism Management, 28, 175-187.

Chen, C. F., \& Tsai, D. C. (2007). How destination image and evaluative factors affect behavioral intentions? . Tourism Management, 28, 11151122.

Chi, C., \& Qu, H. (2008). Examining the structural relationships of destination image, tourist satisfaction and destination loyalty: An integrated approach. Tourism Management, 29, 624-636.

Gallarza, M. G., Saura, I. G., \& Garci'a, H. C. (n.d.). Destination image towards a conceptual framework. Annals of Tourism Research, 29, 56-78.

Hurriyati, R. (2005). Bauran Pemasaran dan Loyalitas Konsumen. Bandung: Alfabeta.

Kotler, P., \& Keller, K. L. (2009). Manajemen Pemasaran (13 ed.). Jakarta, Indonesia: Erlangga.

Lin, C. (2012). Effects of Cuisine Experience, Psychological WellBeing, and Self-Health Perception on The Revisit Intention of Hot Springs Tourist. Journal of Hospitality \& Tourism Research, 1-22.

Liu, X., Li, J., \& Kim, W. (2015). The Role of Travel Experience in the Structural Relationships Among Tourists Perceived Image, Satisfaction, and Behavioral Intentions. Tourism and Hospitality Research, 17(2), 1-12.

Mohan, L. J. (2010). Effect of destination image on attendance at team sporting events. Tourism and Hospitality Research, 10(3), 157-170.

Rageh, A., Melewar, T., \& Woodside, A. (2013). Using Netnography Research Method to Reveal the Underlying Dimension of the Costumer/ Tourist Experience. Qualitative Market Research: An International Journal, 16(2), 126-149.

Sekaran, U., \& Bougie, R. (2016). Research methods for business: A skill building approach. John Wiley \& Sons.
Sulistya, A. (2016). Tren Perkembangan Pariwisata Daerah Istimewa Yogyakarta Periode 2006-2014. Undergraduate Thesis, Universitas Sanata Dharma, Yogyakarta.

Yuniawati, Y., \& Finardi, A. (2016). Pengaruh Customer Experience Terhadap Revisit Intention di Taman Wisata Alam Gunung Tangkuban Perahu. THE Journal: Tourism and Hospitality Essentials Journal, 6(1), 983-994. 